\title{
Behandling av melanommetastaser på ekstremitetene
}

\author{
Sammendrag \\ Bakgrunn. I perioden 1977-99 ble de \\ fleste pasienter ved Radiumhospitalet \\ med melanommetastaser på ekstremi- \\ tetene behandlet med intraarteriell \\ kjemoterapi kombinert med strålebe- \\ handling. Vi har evaluert resultatene \\ av denne behandlingen som nå er blitt \\ erstattet med annen behandling liso- \\ lert perfusjonsbehandling med melfa- \\ lan og tumornekrosefaktor).
}

Materiale og metode. Vi har gjennomgått journalene til pasienter ved Radiumhospitalet med ekstremitetslokaliserte metastaser fra malignt melanom som fikk kjemoterapi med 5-(3,3 dimetyl-1-triazeno)imidazole4-karboksamid (DTIC) intraarterielt i perioden 1977-99.

Resultater. 36 pasienter hadde fått slik behandling. Hos 30 pasienter ble induksjonsbehandlingen kombinert med strålebehandling mot tumorområdet. Ved avsluttet behandling var sykdommen i komplett remisjon hos 24 pasienter. 12 av disse hadde fått fjernet alle metastaser kirurgisk før behandling. Ni pasienter oppnådde partiell remisjon. Sykdommen progredierte hos tre av pasientene. Median observasjonstid var 49 måneder. 15 av totalt 31 pasienter som hadde fått behandling for metastaser på underekstremiteten, var i live etter fem år, og sju av disse var $\mathrm{i}$ live etter $\mathrm{ti}$ år. Tre pasienter med tidligere metastaser på underekstremiteten var døde av annen sykdom. I ett tilfelle førte den intraarterielle kateteriseringen til alvorlig aortaskade.

Fortolkning. Det er mulig å oppnå langvarig lokal kontroll med kjemoterapi kombinert med strålebehandling ved ekstremitetslokaliserte metastaser fra melanom.

\author{
Kari Dolven Jacobsen \\ kari.dolven.jacobsen@radiumhospitalet.no \\ Johan Tausjø \\ Kreftklinikken \\ Bjarne Hager \\ Bilde- og intervensjonsklinikken \\ Oslo universitetssykehus, Radiumhospitalet \\ Montebello \\ 0310 Oslo

\section{Stein Gundersen †} \\ Medisinsk avdeling \\ Sykehuset Østfold \\ Fredrikstad
}

Fjernmetastaser fra malignt melanom er relativt lite påvirkelig av cytostatika. 5-(3,3 dimetyl-1-triazeno)imidazole-4-karboksamid (DTIC) er fortsatt det mest brukte cytostatikum, og 10-20\% av pasientene responderer på denne behandlingen gitt systemisk. Responsen er forbigående, med median varighet 6-7 måneder $(1,2)$. Temozolomid er et nytt medikament som tas som tabletter. Sammenliknende undersøkelser med DTIC viser at responsraten er tilnærmet den samme (3). Kjemoterapi gitt intraarterielt gir høyere konsentrasjon av stoffet til tumor i det perfunderte området enn systemisk behandling. Strålebehandling kan gi god palliasjon og lokal kontroll ved metastaser fra malignt melanom med objektiv remisjon hos $50 \%$ av pasientene (4). Det er imidlertid store variasjoner i strålefølsomhet, bl.a. avhengig av tumors størrelse, lokalisasjon og fraksjonsdose. Strålebehandling kombinert med kjemoterapi er mer effektivt enn hver av disse behandlingene gitt alene (5).

I noen tilfeller med kutane og subkutane metastaser lokalisert til ekstremiteter (in transit-metastaser) går det lang tid før pasienten i tillegg får fjernmetastaser. Ved metastaser til ekstremitet har primærtumor vanligvis vært lokalisert til samme ekstremitet. Pasienter med slike metastaser kan ved intensiv lokal behandling oppnå langvarig, komplett remisjon. Eksempler på slik behandling er kjemoterapi med DTIC gitt intraarterielt til ekstremiteten kombinert med strålebehandling (6), og isolert perfusjonsbehandling (ILP) med melfalan ev. kombinert med TNF- $\alpha(7,8)$. Intraarteriell kjemoterapi ble gitt allerede i 1957 til en melanompasient med hjernemetastase, uten effekt (9). I 1969 fikk den første pasienten med melanommetastaser på underekstremiteten intraarteriell kjemoterapi med DTIC (10). Einhorn og medarbeidere rapporterte i 1973 en responsrate på $40 \%$ med intraarteriell perfusjon med DTIC ved inoperable melanommetastaser lokalisert henholdsvis til underekstremitet, aksille, hals, lever eller genitalslimhinne, men effekten var kortvarig (11).

I 1977 ble det ved Radiumhospitalet startet kombinasjonsbehandling med intraarteriell kjemoterapi og strålebehandling til pasienter med ekstremitetslokaliserte metastaser fra melanom. Gundersen og medarbeidere rapporterte i 1985 at etter behandling av 12 pasienter med metastaser lokalisert til underekstremitet gikk sykdommen i komplett remisjon hos samtlige $(6,12)$. Tidligere ble slike pasienter behandlet med gjentatte kirurgiske ekstirpasjoner av metastaser, ev. kombinert med strålebehandling mot mindre områder. Det endelige utfallet ble ofte utvikling av fjernmetastaser og ev. amputasjon av ekstremiteten (13).

\section{Materiale og metode}

Vi har retrospektivt gått gjennom journalene til pasienter ved Radiumhospitalet med ekstremitetslokaliserte metastaser fra malignt melanom som fikk kjemoterapi med 5-(3,3 dimetyl-1-triazeno)imidazole-4-karboksamid (DTIC) intraarterielt i perioden 1977-99. Behandlingsresultatet for noen av pasientene som inngår i dette materialet er også tidligere publisert $(6,12)$. Pasientene kom fra hele Norge, da denne behandlingen ikke ble gitt ved andre sykehus, og da det ikke var noen god alternativ behandling.

Det ble utført radiologiske undersøkelser før behandlingen for å utelukke metastaser i andre regioner. Pasienter som hadde vært behandlet for eller fikk påvist regionale lymfeknutemetastaser eller fjernmetastaser, fikk ikke intraarteriell kjemoterapi. Siden 1989 har kun pasienter med metastaser lokalisert til underekstremitet og uten påvisbare lymfeknutemetastaser eller fjernmetastaser ved

\section{Hovedbudskap}

- Pasienter med kutane og subkutane melanommetastaser lokalisert til underekstremiteter kan leve lenge, opptil flere år før det påvises fjernmetastaser

- Intensivbehandling lokalt av slike metastaser kan gi langvarige, komplette remisjoner 
Tabell 1 Demografiske data for 36 pasienter med ekstremitetslokaliserte metastaser fra malignt melanom som fikk intraarteriell kjemoterapi ved Radiumhospitalet i perioden 1977-99. Antall hvis ikke annet er angitt

\begin{tabular}{|c|c|}
\hline Antall pasienter & 36 \\
\hline Kvinner & 26 \\
\hline Menn & 10 \\
\hline Alder ved sykdomsdebut (år, median) & 55 \\
\hline \multicolumn{2}{|l|}{ Primærtumors lokalisasjon } \\
\hline Underekstremitet & 29 \\
\hline Overekstremitet & 5 \\
\hline Ukjent & 2 \\
\hline
\end{tabular}

Tabell 2 Behandling av 36 pasienter med ekstremitetslokaliserte metastaser fra malignt melanom som fikk intraarteriell kjemo terapi ved Radiumhospitalet i perioden 1977-99. Antall i de ulike kategoriene angis

Kjemoterapi
Induksjonsbehandling
DTIC
DTIC, cisplatin, vindecin
Vedlikeholdsbehandling'
Kateterspissens plassering

\begin{tabular}{|c|c|}
\hline A. iliaca & 30 \\
\hline A. femoralis & 1 \\
\hline A. axillaris & 4 \\
\hline A. subclavia & 1 \\
\hline \multicolumn{2}{|l|}{ Strålebehandling } \\
\hline Kombinert med kjemoterapi & 30 \\
\hline Før/etter kjemoterapi & 3 \\
\hline Ingen & 3 \\
\hline \multicolumn{2}{|l|}{ Fraksjonering ${ }^{2}$} \\
\hline $3 \mathrm{~Gy} \times 12$ & 27 \\
\hline $3 \mathrm{~Gy} \times 11$ & 1 \\
\hline $4,8 \mathrm{~Gy} \times 7$ & 1 \\
\hline $4 \mathrm{~Gy} \times 9$ & 1 \\
\hline
\end{tabular}

CT-undersøkelser av thorax, abdomen og bekken med lysker fått denne form for kombinasjonsbehandling ved Radiumhospitalet.

Melanommetastasene ble målt og fotografert før og etter avsluttet behandling og senere ved regelmessige kontroller med økende intervall. Noen pasienter kommer fortsatt til årlig kontroll. De fleste pasienter som fikk residiv av sykdommen, fikk behandling ved Radiumhospitalet frem til de døde.

Intraarteriell kjemoterapi ble gitt selektivt i arterien som forsynte ekstremiteten der metastasene var lokalisert. Det infunderte stoffet hadde derfor en høy konsentrasjon ved infusjonen, og den kunne vare i flere timer før det ga en mer systemisk virkning. Kateterspissens plassering ble kontrollert røntgenologisk hver morgen før kur.

DTIC initialt løst i $1000 \mathrm{ml} \mathrm{0,9 \%} \mathrm{NaCl}$ og senere i $250 \mathrm{ml}$ ble gitt som 30 minutters infusjon. Kateteret ble holdt åpent med kontinuerlig heparinisert saltvannsinfusjon. En spesial trykkmansjett holdt trykket over det arterielle $(300 \mathrm{~mm} \mathrm{Hg})$. Pasientene som fikk femdagerskurer, fikk DTIC $150 \mathrm{mg}$ like før og samme dose seks timer etter strålebehandling de fire første dagene og morgendose den femte dagen.

Strålebehandlingen ble gitt med en kobolt 60-maskin eller med en lineær akselerator, og det ble lagt bolus over hudlesjonene. Bolus er voks eller annet vevsekvivalent materiale som ble lagt på huden for å oppnå full stråledose til hudlesjonene.

\section{Etikk}

Registrering av pasientopplysninger er godkjent av personvernombudet.

\section{Resultater}

\section{Pasientkarakteristika}

I perioden $1977-99$ ble 36 pasienter med ekstremitetslokaliserte metastaser fra malignt melanom behandlet med intraarteriell kjemoterapi ved Radiumhospitalet. Første kur ble kombinert med strålebehandling mot tumorområdet hos 30 pasienter. Median alder ved sykdomsdebut var 55 år (spredning 21-77 år) (tab 1).

\section{Gjennomføring av behandlingen}

Ved induksjonsbehandlingen ble kateteriseringen gjort via a. femoralis hos 26 pasienter, a. brachialis hos ni pasienter og a. subclavia hos en pasient. Kateteret lå permanent i fem dager hos 25 pasienter og i 14 dager hos en pasient der behandlingen ble gjentatt etter to måneder. Disse pasientene fikk DTIC daglig den tiden de hadde kateter. Åtte pasienter fikk kur bare en dag. Hos to pasienter ble kateteriseringen gjort via lysken hver annen dag fire ganger av tekniske årsaker.

Ved de videre kurene i induksjonsbehandlingen ble kateteriseringen gjort via a. femoralis hos seks pasienter der man tidligere hadde brukt a. brachialis som kateterinngang. Kateterspissens plassering fremgår av tabell 2.

DTIC ble kombinert med cisplatin og vindecin ved en eller flere kurer hos fire pasienter. Pasienten som hadde kateter permanent i 14 dager, fikk DTIC (125-150 mg) to ganger daglig under hele oppholdet ved begge innleggelser.

Den intraarterielle kjemoterapien ble kombinert med stråleterapi hos 30 pasienter. Tre pasienter fikk strålebehandling henholdsvis en og fem måneder før eller seks måneder etter kjemoterapi. Tre pasienter fikk ingen strålebehandling. 25 pasienter fikk 12 fraksjoner med 3 Gy mot hele eller større deler av ekstremiteten, to fikk 12 frak- sjoner med 3 Gy mot flere mindre felter (tab 2).

Etter den initiale kombinasjonsbehandlingen fikk 28 pasienter endagskurer med DTIC $800 \mathrm{mg} / \mathrm{m}^{2}$ intraarterielt over en time en til sju ganger hver fjerde uke (tab 2). Åtte pasienter fikk ingen flere kurer intraarterielt pga. progrediering, komplikasjoner, lang induksjonsbehandling eller av religiøse årsaker.

\section{Respons}

Ved avsluttet behandling var 33 pasienter i komplett eller partiell remisjon (tab 3, ramme 1) (14). 30 av disse pasientene hadde hatt metastaser lokalisert til underekstremitet og tre pasienter til overekstremitet. 24 pasienter var residivfrie, dvs. i komplett remisjon, ved avsluttet behandling. 12 av de 24 pasientene hadde fått fjernet alt påvisbart tumorvev før behandlingsstart. En pasient oppnådde komplett remisjon som varte i ni måneder med kjemoterapi alene. To av de tre pasientene med sykdomsprogrediering hadde metastaser lokalisert til overekstremitet.

\section{Overlevelse}

Median tid fra diagnose av primærtumor til residiv var 17 måneder og fra residiv til intraarteriell kjemoterapi 13 måneder. Median observasjonstid etter behandling var 49 måneder (spredning 1-339 måneder) (tab 3). For 15 pasienter, alle med metastaser lokalisert til underekstremitet, var observasjonstiden mer enn fem år etter avsluttet behandling. 13 av disse pasientene var kvinner. For sju pasienter var observasjonstiden mer enn ti år. Disse var kvinner og hadde hatt metastaser lokalisert til underekstremitet. Tre pasienter med tidligere metastaser i underekstremitet døde av annen sykdom hhv. 15 år, 14 måneder og 15 måneder etter avsluttet behandling uten at det var tegn til residiv. Median levetid for de fem pasientene med metastaser til overekstremitet var 11 måneder (spredning 1-22 måneder).

\section{Bivirkninger}

Alvorlige komplikasjoner av behandlingen ble registrert hos to pasienter (hhv. aortaskade og uttalte hudforandringer/nekrose i behandlet ekstremitet). Videre var det en stråledermatitt, en subkutan fibrose/leddkontraktur og en liten venetrombe. Bivirkningene for øvrig var moderate med noe forbigående økt trettbarhet og ødem i den behandlede ekstremiteten. Kvalme og oppkast var av mild form hos de fleste pasienter ved DTIC-doser $<800 \mathrm{mg} / \mathrm{m}^{2}$. Ved enkeltdoser på $800 \mathrm{mg} / \mathrm{m}^{2}$ forekom moderat kvalme og hos enkelte pasienter oppkast. Ingen pasienter utviklet alvorlig myelosuppresjon eller tegn til reaksjon rundt kateterinngangen.

\section{Diskusjon}

De fleste pasientene responderte på behandling med intraarteriell kjemoterapi kombinert med strålebehandling mot melanomme- 
Tabell 3 Resultat for 36 pasienter med ekstremitetslokaliserte metastaser fra malign melanom behandlet med intraarteriell kjemoterapi ved Radiumhospitalet i perioden 1977-99. Antall dersom ikke annet er angitt

\begin{tabular}{|cc|}
\hline Remisjon & 33 \\
\hline Komplett & 24 \\
\hline Metastase i overekstremitet & 11 \\
\hline Metastase i underekstremitet & $23^{2}$ \\
\hline Partiell & 9 \\
\hline Metastase i overekstremitet & 2 \\
\hline Metastase i underekstremitet & 7 \\
\hline Progrediering & 3 \\
\hline Metastase i overekstremitet & 2 \\
\hline Metastase i underekstremitet & 1 \\
\hline Observasjonstid (md., median) & 49 \\
\hline$>5$ år (62-339 md.) & $15^{3}$ \\
\hline 10 år & 7 \\
\hline
\end{tabular}

1 Pasienten hadde fått fjernet alt påvisbart tumorvev 211 pasienter hadde fått fjernet alt påvisbart tumorvev

${ }^{3}$ Pasientene hadde metastaser lokalisert til underekstremitet

tastaser lokalisert til en underekstremitet (fig 1). Resultatene viser at flere pasienter med ekstremitetslokaliserte metastaser kan leve i mange år og være i komplett eller partiell remisjon etter intensiv lokal behandling. Dette er i samsvar med tidligere funn $(6,12)$.

Pasienter som ble bestrålt på mindre felter, fikk nye subkutane metastaser mellom feltene. Strålebehandlingen bør derfor sannsynligvis gis mot hele leggen, låret eller begge deler ved kombinasjonsbehandling.

Den relative effekten av kombinert strålebehandling og intraarteriell kjemoterapi med henblikk på de terapeutiske resultatene er uklar. Den komplette remisjon i ni måneder med kjemoterapi alene hos en pasient indikerer at intraarteriell DTIC alene kan være effektivt, men med forbigående effekt. Dette har også vært rapportert tidligere $(11,15)$. Noen pasienter med ekstremitetslokaliserte metastaser ble behandlet med systemisk kjemoterapi alene pga. tekniske vanskeligheter
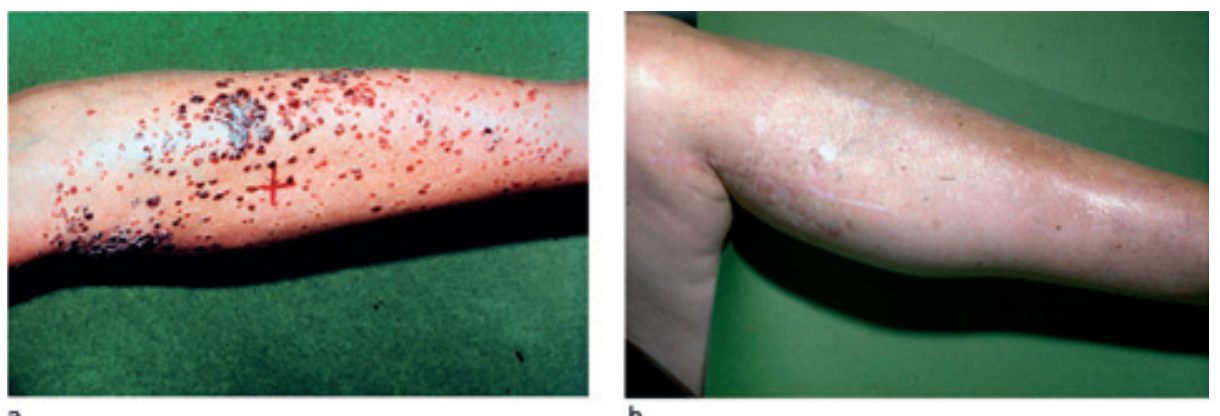

Figur 1 Ekstremitetslokaliserte melanommetastaser al før og b) 39 måneder etter kombinasjonsbehandling med intraarteriell 5-(3,3 dimetyl-1-triazeno)imidazole-4-karboksamid (DTIC) og strålebehandling i forbindelse med kateterisering eller pga. høy alder. Resultatet av denne behandlingen ved Radiumhospitalet er ikke gjennomgått, men utenlandske studier har vist langt dårligere resultater enn ved intraarteriell behandling (16).

Effekten av behandlingen var bedre hos kvinner enn hos menn i dette materialet. Denne forskjellen er også vist i tidligere studier med både intraarteriell og systemisk kjemoterapi $(11,17)$.

Det er uklart hvor mange kurer som burde vært gitt etter induksjonsbehandlingen. Ved Radiumhospitalet valgte man fra 1986 å gi tre endagskurer med DTIC intraarterielt hver fjerde uke etter avsluttet strålebehandling. Det er også uklarhet rundt optimal fraksjonering og måldose. Disse spørsmål kunne vært løst ved randomiserte studier i samarbeid med andre kreftsentre.

Vi konkluderer med at kombinert strålebehandling og intraarteriell DTIC gitt til pasienter med metastatisk melanom lokalisert til underekstremitet er en effektiv behandling. Siden 1999 er denne behandlingen blitt erstattet med isolert perfusjonsbehandling. Denne behandlingen foregår over noen timer kun en dag, og pasienten får et kortvarig sykehusopphold. Det lages da et lukket system ved å legge kateter $\mathrm{i}$ arterie og vene til aktuelle ekstremitet. Disse kobles til et eksternt kretsløp der det settes cytostatika, vanligvis melfalan ev. kombinert med tumornekrosefaktor. Dette gjør det mulig å gi høye doser cytostatika med relativt lite systemiske bivirkninger og vanligvis akseptabel regional toksisitet. Behandlingen gis under mild hypertermi i vevet. Den nye behandlingen ble startet i Norge da det forelå gode resultater fra utenlandske studier (8). Studier har vist at sykdommen responderer på denne behandlingen hos $90 \%$ av pasientene hvorav $50 \%$ oppnår komplett remisjon med melfalan alene. $70 \%$ oppnår komplett remisjon ved kombinasjon med TNF- $\alpha(7,8)$. Det var også ressursmessige og praktiske årsaker til at tidligere behandling ble forlatt.

Ekstremitetslokaliserte metastaser fra malignt melanom forekommer sjelden, men kan behandles med godt resultat. Dette krever at de som utfører denne behandlingen får

opprettholdt erfaring og kompetanse både i klinisk bedømmelse og praktisk gjennomføring. Det er generell enighet om at pasienter med ekstremitetslokaliserte metastaser derfor bør henvises til Oslo universitetssykehus, Radiumhospitalet som har landsfunksjon for denne formen for intensiv regional behandling.

\section{Oppgitte interessekonflikter: Ingen}

\section{Litteratur}

1. Serrone L, Zeuli M, Sega FM et al. Dacarbazinebased chemotherapy for metastatic melanoma: thirty-year experience overview. J Exp Clin Cancer Res 2000; 19: 21-34.

2. Eggermont AM, Kirkwood JM. Re-evaluating the role of dacarbazine in metastatic melanoma: what have we learned in 30 years? Eur J Cancer 2004; 40: $1825-36$

3. Danson SJ, Middleton MR. Temozolomide: a novel oral alkylating agent. Expert Rev Anticancer Ther 2001; 1: 13-9.

4. Fenig E, Eidelevich E, Njuguna E. Role of radiation therapy in the management of cutaneous malignant melanoma. Am J Clin Oncol 1999: 22: 184-6.

. Rofstad EK, Brustad T, Johannessen JV et al. Effect of cobalt- 60 gamma rays and DTIC $15-13,3$ dimethyl-1-triazeno)-imidazole-4-carboxamidel on human malignant melanomas grown in athymic nude mice. Br J Radiol 1977; 50: 314-20.

6. Gundersen S, Hager B, Tausjø J. Strålebehandling og intraarteriell kjemoterapi med 5-13,3 dimetyl-1 triazeno)imidazole-4-karboksamid. Effekt ved ekstremitetslokalisert malignt melanom. Tidsskr Nor Lægeforen 1985; 105: 1617-9.

7. Lejeune FJ, Kroon BB, Di Filippo F et al. Isolated limb perfusion: the European experience. Surg Oncol Clin N Am 2001; 10: 821-32. 
8. Lienard D, Eggermont AM, Kroon BB et al. Isolated limb perfusion in primary and recurrent melanoma: indications and results. Semin Surg Oncol 1998; 14: 202-9.

9. Sullivan RD, Miller E, Sikes MP. Antimetabolite metabolite combination cancer chemotherapy. Effects of intraarterial methotrexate - intramuscular Citrovorum factor therapy in human cancer. Cancer 1959; 12: 1248-62.

10. Savlov ED, Hall TC. Response of localized melanoma to intra-arterial dimethyl triazeno imidazole carboxamide. A case report. J Surg Oncol 1970; 2: 341-7.

11. Einhorn LH, McBride CM, Luce JK et al. Intraarterial infusion therapy with 5-(3,3-dimethyl-1triazeno)imidazole-4-carboxamide (NSC 45388) for malignant melanoma. Cancer 1973; 32: 749-55.

12. Gundersen S, Hager B, Tausjo J. Radiation in combination with intra-arterial infusion therapy with dacarbazine for metastatic malignant melanoma localized to a lower extremity. Cancer Treat Rep 1986; 70: 1015-7.

13. Jaques DP, Coit DG, Brennan MF. Major amputation for advanced malignant melanoma. Surg Gynecol Obstet 1991; 169: 1-6.

14. Therasse P, Arbuck SG, Eisenhauer EA et al. New guidelines to evaluate the response to treatment in solid tumors (RECIST Guidelines). J Natl Cancer Inst 2000; 92: 205-16.

15. Savlov ED, Hall TC, Oberfield RA. Intra-arterial therapy of melanoma with dimethyl triazeno imidazole carboxamide (NSC-45388). Cancer 1971; 28: $1161-4$

16. Wong JH, Cagle LA, Kopald KH et al. Natural history and selective management of in transit melanoma. J Surg Oncol 1990; 44: 146-50.

17. Luce JK. Chemotherapy of malignant melanoma. Cancer 1972; 30: 1604-15.

Manuskriptet ble mottatt 27.6. 2007 og godkjent 15.10. 2009. Medisinske redaktører Jens Bjørheim og Siri Lunde. 